\title{
Effect of Zn Content on Orthopedic Mg Alloy as Smart Implant
}

\author{
OMYMA RAMADAN MOHAMMED KHALIFA, \\ ENSHERAH ABDEL-WAHAB ABD ELHAMID, \\ AISHA KASSAB, AMAL HEMIDA TILP, \\ MARWA MOHAMED MOHAMED MOHAMED ESMAIL* \\ Faculty of Girls, Arts, Science and Education. Ain Shams University, Egypt
}

\begin{abstract}
In recent years, smart implants take the most attention in the field of bone manufacturing. Our study seeks to develop the biodegradability of $\mathrm{Mg}$ alloys to use orthopedic implants for the biomedical applications to avoid post removal of the implant. $\mathrm{Mg}$ and Zn are very important to human body and have no toxicity. Mg - 6\% wt Zn biodegradability is studied in simulated body fluid for two and four weeks. Four electro-deposition bathes are used to deposit a coat on the substrate to improve the corrosion resistance of this alloy in the media of simulated body fluid. The following analyses were studied to emphasize the research aim. Scanning electron microscope (SEM), Energy dispersive XRay (EDX) analysis shows the surface morphology and the elements of the coat phases components. The results also confirmed by X-Ray diffraction Pattern (XRD) that show the phases that confirmed the formation of hydroxyapatite HA phase, Fourier-Transform Infrared Spectroscopy (FTIR) to investigate the functional groups of the phases coats that confirm the formation of hydroxyapatite and the electrochemical measurements that investigate the improvement of corrosion resistance. The results indicated that the fourth bath gives the best coat and four weeks immersion gives more corrosion resistance than two weeks.
\end{abstract}

Keywords:Smart implant, Mg-6\%Zn, hydroxyapatite, Electro-deposition bathes, Corrosion resistance

\section{Introduction}

Smart implants or biodegradable implants development in simulated body fluid is the powerful aim to attract the interest of scientists in the few recent years.[1,2]. The main advantage is to dispense with the second surgery to extract the slice from the body after the stage of full recovery $[1,3-5]$. Element alloying with magnesium is a good bath to enhance its corrosion resistance and the mechanical proprieties. [2, 4] Magnesium implants have been enhanced to simulate the formation of new bone when used as bone fixtures [6]. Zinc is essential element in the human body and used to rise the corrosion potential and decrease corrosion rate of $\mathrm{Mg}$. [7, 8] Zinc can passivate anodic kinetic of $\mathrm{Mg}$ in corrosive medium due to the formation of $\mathrm{ZnO}$-based coating [9, 10] and also decrease the deleterious effects of metallic impurities as $\mathrm{Fe}$ and $\mathrm{Ni}$ [11]. Some recent studies discussed the improvement of the Mg-Zn binary alloys. [2] Zinc can be added less than $1 \mathrm{wt} \%$ or up to $6 \mathrm{wt} \%$ for biomedical application [12], $6.2 \mathrm{wt} \%$ [13] at the eutectic temperature $341^{\circ} \mathrm{C}[2,14]$. Also shuhua Cai [2] study the $\mathrm{Mg}-\mathrm{Zn}$ binary alloy $(\mathrm{Zn}=1,5$ and 7\%) and enhanced the corrosion resistance of the alloy. $\mathrm{Mg}-1 \% \mathrm{Zn}$ studied and enhanced it's mechanical prosperities and corrosion resistance by the addition of $\mathrm{Zn}$ as alloying element. [15, 16] Mg-3\% Zn alloy was studied by different heat treatment to enhance corrosion resistance. [17] $\mathrm{Mg}-6 \% \mathrm{Zn}$ alloy has suitable tensile, strength and elongation for implant application [18,19]. Calcium phosphate bioceramics, hydroxyapatite have similar chemical composition to the bone tissue. [20-23]

*email:marwaesmail4m@yahoo.com 


\section{Materials and methods}

\section{1 - Materials}

Mg- 6\% Zn alloy sheets

Specimens of $\mathrm{Mg}-6 \%$ wt $\mathrm{Zn}$ is cutting with dimensions $2 \times 2.5 \mathrm{~cm}^{2}$ and $5 \mathrm{~mm}$ thickness. The alloy with a chemical composition of $\mathrm{Mg}-6 \% \mathrm{Zn}$ is prepared from pure $\mathrm{Mg}$ and $\mathrm{Zn}$ using a laboratory resistance furnace. The melt is transferred to a semi-continuous casting machine at $900^{\circ} \mathrm{C}$.

\subsection{Preparation of Electrolyte Solution}

Electroplating bathes include $\mathrm{Ca}\left(\mathrm{NO}_{3}\right)_{2} .4 \mathrm{H}_{2} \mathrm{O}$ as the calcium ion source, ammonium di-hydrogen phosphate $\mathrm{NH}_{4} \mathrm{H}_{4} \mathrm{PO}_{4}$ as the phosphate ion source, sodium nitrate $\mathrm{NaNO}_{3}$ to increase conductivity, hydrogen peroxide $\left(\mathrm{H}_{2} \mathrm{O}_{2}\right)$ to erase in Table (1).

Table 1. Chemical composition of coating baths

\begin{tabular}{|l|l|l|l|l|}
\hline Coat & Bath I & Bath II & Bath III & Bath IV \\
\cline { 1 - 4 } Composition & & & & \\
\hline $\mathrm{CaNO}_{3}$ & $9.90 \mathrm{~g} / \mathrm{l}$ & $9.90 \mathrm{~g} / \mathrm{l}$ & $11.00 \mathrm{~g} / \mathrm{l}$ & $11.00 \mathrm{~g} / \mathrm{l}$ \\
\hline $\mathrm{NH}_{4} \mathrm{H}_{2} \mathrm{PO}_{4}$ & $2.87 \mathrm{~g} / \mathrm{l}$ & $4.00 \mathrm{~g} / \mathrm{l}$ & $2.87 \mathrm{~g} / \mathrm{l}$ & $4.00 \mathrm{~g} / \mathrm{l}$ \\
\hline $\mathrm{NaNO}_{3}$ & $1.27 \mathrm{~g} / \mathrm{l}$ & $1.27 \mathrm{~g} / \mathrm{l}$ & $1.27 \mathrm{~g} / \mathrm{l}$ & $1.27 \mathrm{~g} / 1$ \\
\hline $\mathrm{Na}_{3} \mathrm{PO}_{4}$ & $2.00 \mathrm{~g} / \mathrm{l}$ & $2.00 \mathrm{~g} / \mathrm{l}$ & $2.00 \mathrm{~g} / \mathrm{l}$ & $2.00 \mathrm{~g} / \mathrm{l}$ \\
\hline $\mathrm{H}_{2} \mathrm{O}_{2}$ & $20.00 \mathrm{ml} / \mathrm{l}$ & $20.00 \mathrm{ml} / 1$ & $20.00 \mathrm{ml} / 1$ & $20.00 \mathrm{ml} / 1$ \\
\hline
\end{tabular}

The optimum conditions are $p \mathrm{H} 7.4$ and temperature $37^{\circ} \mathrm{C}$. Fixed potential was set to $1.4 \mathrm{~V}$ and time $30 \mathrm{~min}$. The circuit is connected so that, the magnesium alloy substrate became negatively charged (as cathode).

Table 2. Chemical composition of simulated body fluid (SBF)[3]

\begin{tabular}{|c|c|c|c|c|c|c|c|c|}
\hline Chemicals & $\mathrm{NaCl}$ & $\mathrm{KCl}$ & $\mathrm{CaCl}_{2}$ & $\mathrm{NaHCO}_{3}$ & $\mathrm{MgSO}_{4}$ & $\mathrm{KH}_{2} \mathrm{PO}_{4}$ & $\mathrm{Na}_{2} \mathrm{HPO}_{4}$ & Glucose \\
\hline Wt. $(\mathrm{gm} / \mathrm{l})$ & 8.8 & 0.4 & 0.14 & 0.35 & 0.2 & 0.1 & 0.06 & 1 \\
\hline
\end{tabular}

The specimens are mechanically polished abraded to 2000 grit finish with SiC paper, the specimen are carefully rinsed in distilled water, dried with hot dry air and stored in a desiccators if not immediately examined. The samples are weighed before and after plating and the difference in weight is calculated.

\subsection{Coating process}

The cleaned samples are coated electrochemically for a definite time $30 \mathrm{~min}$ at room temperature. Agitation of the solution took place at 250-500 r.p.m. we use four baths for the deposition of coat, I, II, III and VI.

The optimum condition for coating is done for the bath I then, uses the same conditions for the other three bathes in order to compare between them.

\subsection{Surface characterization of the coatings}

The properties of electro-plating coating as plated and after immersion in simulated body fluid (SBF) (Table 2), for 2 and 4 weeks at $37^{\circ} \mathrm{C}$, are investigated. Scanning electron microscope (SEM), FTIR of coatings, X-ray diffraction (XRD), EDAX and corrosion resistance are used for investigation.

\subsection{1- Scanning electron microscope (SEM)}

SEM (Quanta 250 FEG, Taiwan) is used to demonstrate the surface morphology. The examination is carried out on different samples employing an accelerating voltage of 30kv. Samples are mounted using carbon paste to ground them. The results are obtained as computer printout. 


\subsection{2- Fourir-Transform Infrared Spectroscopy (FTIR)}

FTIR spectra are obtained using pearl bruker IFS $125 \mathrm{HR}$ and are recorded in the $4500-400 \mathrm{~cm}^{-1}$ region with $0.0024 \mathrm{~cm}^{-1}$ resolution by using $\mathrm{KBr}$ pellet technique.

\subsection{3- X-ray Diffraction (XRD)}

An X-ray diffractometer (D8 ADVANCE X-RDIFFRACTOMETER, Germany) with copper target and nickel filter is used for identification of the phases, amorphous and crystalline structure of the deposits.

\subsection{4- Corrosion Resistance}

Electrochemical study tests are carried out using a classical three electrode cell with Pt as counter, $\mathrm{Ag} / \mathrm{AgCl}$ electrode as reference electrode, and the samples as working electrode. The potentiodynamic curves are obtained using a model CHInstrument.

\section{Results and discussions}

The surface morphology of the as deposited coating is shown in Figure 1. Figure 1(a) show white flake like structure diversing from center towards prefirphery with different dimensions with grain size $7.91 \mu \mathrm{m}$. Flake-like structure mixed with rodlike morphology was observed on the surface of Figure 1(b) and its grain size $5.87 \mu \mathrm{m}$. Figure 1(c) shows flake-like structure with some black spots with grain size $5.13 \mu$ mand Figure 1(d) shows irregular black flake like structurewith grain size $2.05 \mu \mathrm{m}$.
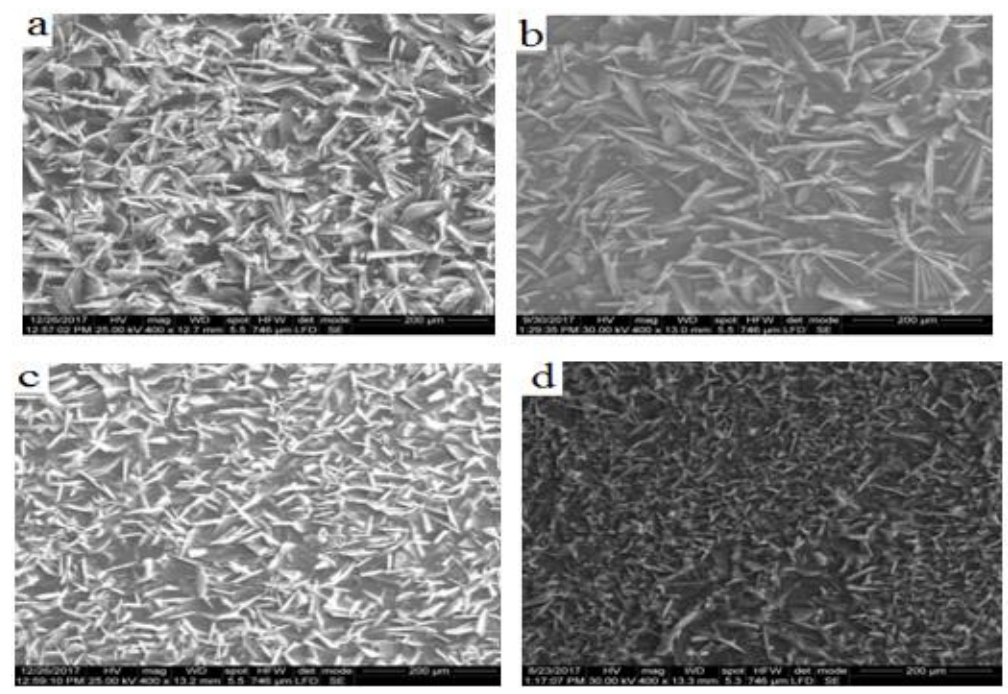

Figure 1. Scanning electron microscope of surface morphology of a) Bath I b) Bath II

Figures 2(a, b) show the surface morphology of the coating obtained from bath I after immersion in simulated body fluid (SBF) for different times, two weeks Figure 2 (a) and four weeks 2(b). The morphology image of Figure 2(a) shows randomly arranged rod like morphology with grain size 9.36 $\mu \mathrm{m}$. Figure 2 (b) appears to be irregular flake-like with grain size $7.10 \mu \mathrm{m}$. 

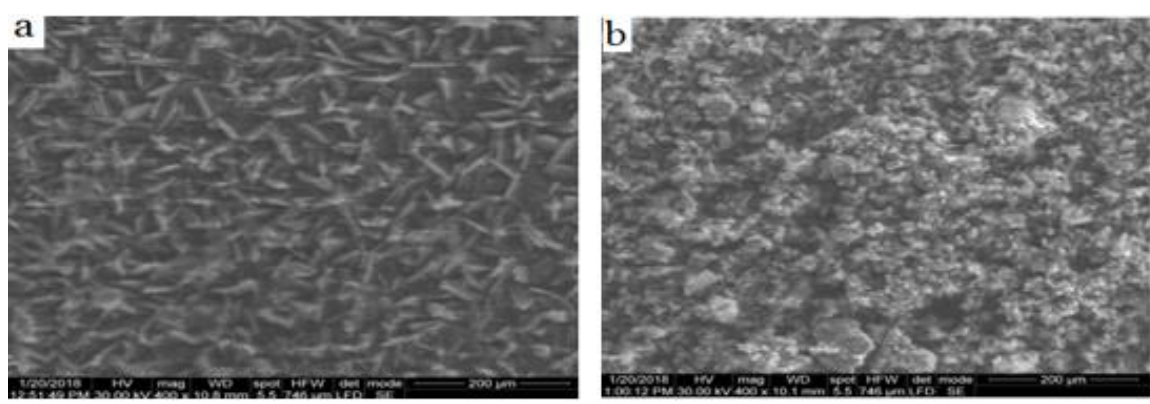

Figure 2. Scanning electron microscope of surface morphology of (Bath I) immersed in simulated body fluid for a) two weeks b) four weeks

Figures 3(a, b) show surface morphology of the coating bath II obtained after immersion of the specimens in simulated body fluid (SBF) solution for two and four weeks. Regular flake-like structure with different dimensions with white spots with grain size $7.82 \mu \mathrm{m}$ was showed in Figure 3(a). Figure 3 (b) showed mixture of flake-like structure with white ones with grain size $6.72 \mu \mathrm{m}$.
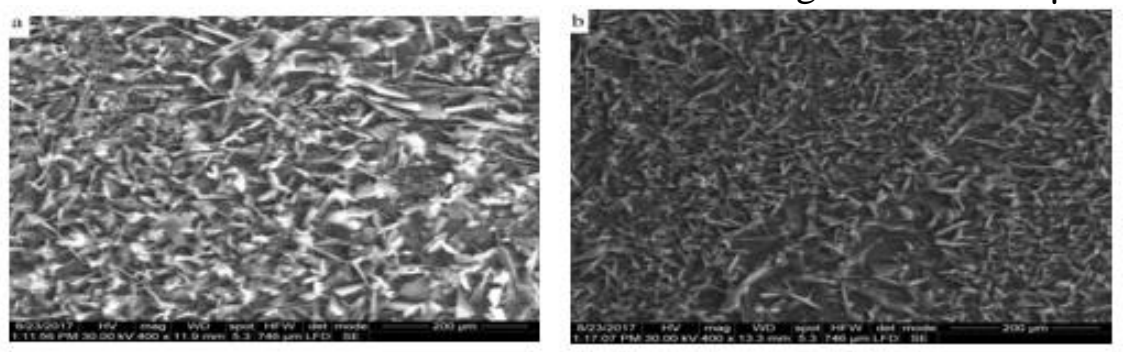

Figure 3. Scanning electron microscope of surface morphology of

(Bath II) immersed in simulated body fluid for a) two weeks b) four weeks

Figures $4(\mathrm{a}, \mathrm{b})$ show irregular shapes with grain size of $7.14 \mu \mathrm{m}$ for two weeks and $5.33 \mu \mathrm{m}$ for four weeks.
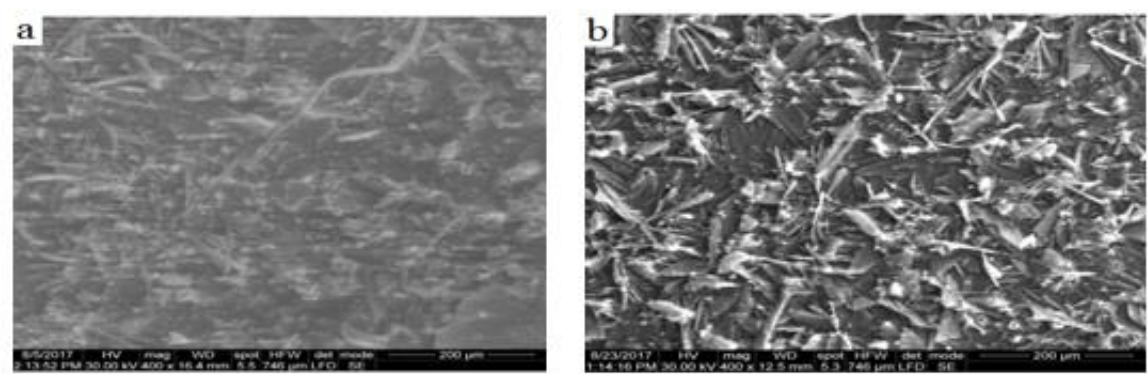

Figure 4. Scanning electron microscope of surface morphology of

(Bath III) immersed in simulated body fluid for a) two weeks b) four weeks

Figures 5(a, b) show the surface morphology images of coating films from bath IV after immersion in SBF for two and four weeks. Figure 5(a) shows flack like particles with white colour with grain size $5.87 \mu \mathrm{m}$. Figure $5(\mathrm{~b})$ shows irregular shape with grain size $2.30 \mu \mathrm{m}$. 

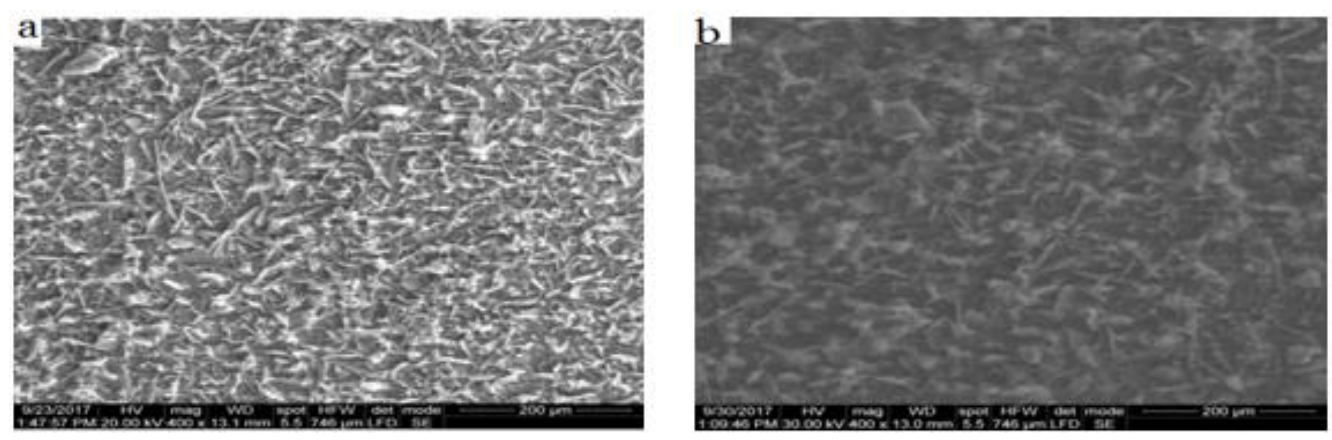

Figure 5. Scanning electron microscope of surface morphology of (Bath IV) immersed in simulated body fluid for a) two weeks b) four weeks

The FTIR spectra of electrodeposited $\mathrm{Mg}-6 \% \mathrm{Zn}$ alloy in the four bathes are shown in Figures. $6(\mathrm{a}-\mathrm{d})$. The most characteristic chemical groups in the FTIR spectra of the four bathes are $\mathrm{PO}_{4}{ }^{-3}, \mathrm{OH}^{-1}$ and $\mathrm{NO}_{3}{ }^{-1}$. Phosphate group $\left(\mathrm{PO}_{4}^{-3}\right)$ forms intensive IR absorption at $560,600 \mathrm{~cm}^{-1}$ and at $1000-1100$ $\mathrm{cm}^{-1}$.Absorbed water band are relatively wide from 3600 to $2600 \mathrm{~cm}^{-1}$ with explicit peak at 870 and $880 \mathrm{~cm}^{-1}$ and more intensive peaks between 1460 and $1530 \mathrm{~cm}^{-1}$. At 3531,3541 and $3543 \mathrm{~cm}^{-1}$ are due to stretching vibration which indicates the presence of water molecule as in Figure 6. The disappearance of the band $3541 \mathrm{~cm}^{-1}$ could be due to the substitution of $\mathrm{OH}^{-1}$ by $\mathrm{NO}_{3}^{-1}$ ions (direct substitution $2 \mathrm{OH}^{-1} \leftrightarrow \mathrm{NO}_{3}{ }^{-1}$ ) into the four bathes. According to Figures 6 a-d the layer precipitated on the surface contained $\mathrm{NO}_{3}{ }^{-1}$ and $\mathrm{PO}_{4}{ }^{-3}$ groups.

FTIR characterization of prepared samples confirms the formation of hydroxyapatite due to the presence of various modes of their functional groups.

The effect of immersion of the coated specimens by bath I in SBF for two and four weeks is shown in Figures 7 (a, b). From the Figures the functional groups $\mathrm{NO}_{3}{ }^{-1}$ and $\mathrm{PO}_{4}{ }^{-3}$ appeared i.e. formation of hydroxyapatite. The functional groups are shown in Figures $8(a, b), 9(a, b)$ and $10(a, b)$ for immersion in bath II, bath III and bath IV for two and four weeks respectively.

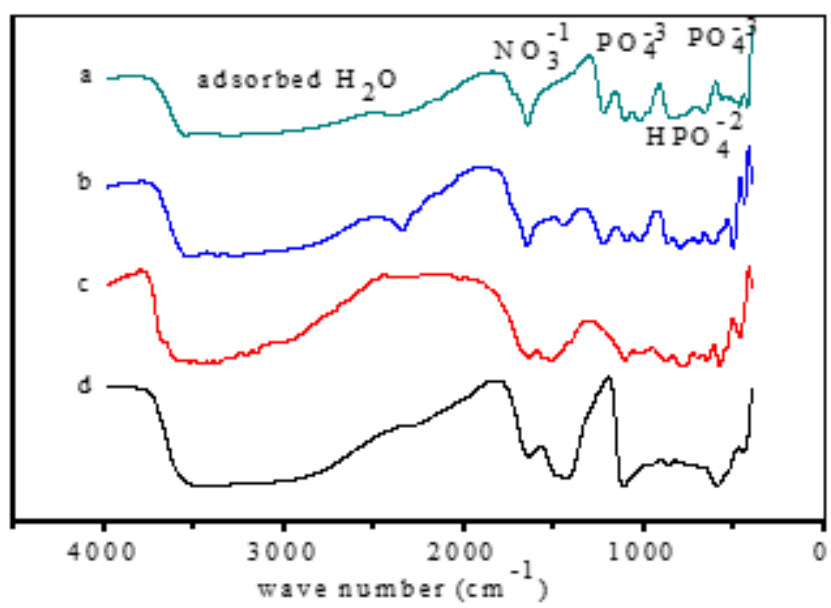

Figure 6. FTIR spectra for $\mathrm{Mg}-6 \% \mathrm{Zn}$ as deposit form a) Bath I b) Bath II c) Bath III d) Bath IV 

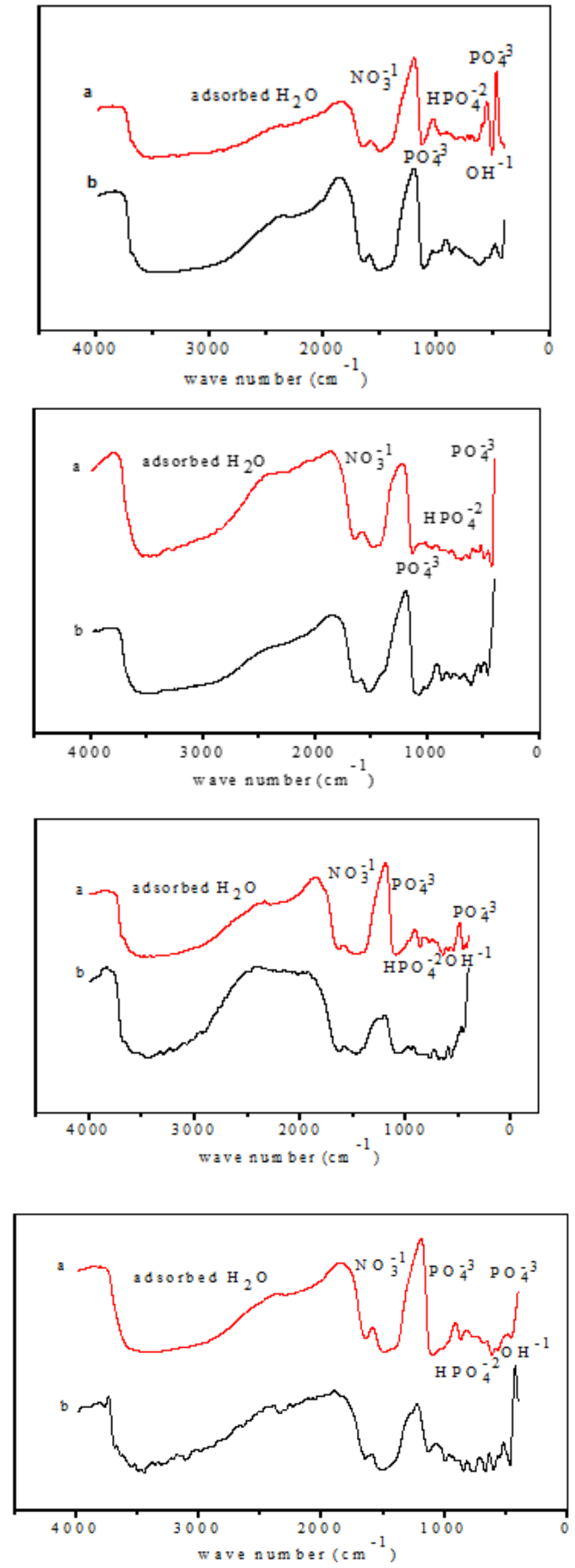

Figure 7. FTIR spectra for Mg$6 \% \mathrm{Zn}$ (Bath I) immersed in SBF only for a) two weeks b) four weeks

Figure 8. FTIR spectra for $\mathrm{Mg}-6 \% \mathrm{Zn}$ (Bath II) immersed in SBF only for a) two weeks b) four weeks

Figure 9. FTIR spectra for $\mathrm{Mg}-6 \% \mathrm{Zn}$ (Bath III) immersed in SBF only for a) two weeks b) four weeks

Figure 10. FTIR spectra for $\mathrm{Mg}-6 \% \mathrm{Zn}$ (Bath IV) immersed in SBF only for a) two weeks b) four weeks 
The XRD patterns of as coated Mg- $6 \% \mathrm{Zn}$ alloy with bath I, II, III and IV are shown in Figures 11(a-d). Figure 11(a) shows sharp peaks at $2 \Theta$ equals $11.76,34.42,35.52$ and 47.95 represent monoclinic calcium phosphate dihydrate $\mathrm{CaHPO}_{4} 2\left(\mathrm{H}_{2} \mathrm{O}\right)$. Other sharp peaks with little heights also represent Brushite calcium phosphate dihydrate. At $2 \Theta$ equal 63.18 represent hexagonal magnesium and also at $2 \Theta$ equals 65, calcium oxide phase is shown. The average grain size of bath I coating which is determined by Scherrer method is about 86 to $63.2 \mathrm{~nm}$. Figures 11(b-d) represent the same phases (monoclinic calcium phosphate dihydrate, hexagonal magnesium and calcium oxide) but accompanied by small positional shifts towards higher or lower angles. The average grain size of the coat in bath II is $72.8-41.6 \mathrm{~nm}$. N.B. All the coatings are crystalline in nature.

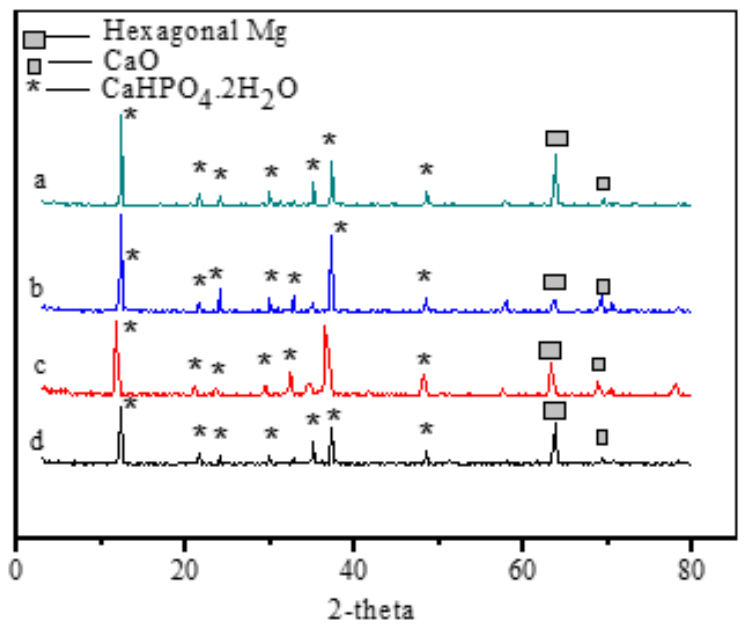

Figure 11. X-ray diffraction patterns of $\mathrm{Mg}-6 \% \mathrm{Zn}$ as deposited from a) Bath I b) Bath II c) Bath III d) Bath IV

Figure 12(a) shows the EDAX analysis of the as deposit coating obtained before immersion in SBF of bath I. Strong peaks of $\mathrm{Ca}, \mathrm{P}, \mathrm{Mg}$ and $\mathrm{O}$ elements are present.

Figures 12 (b-d) show the EDAX analysis of the as deposited samples in bath II, III and IV without immersion in SBF. Also strong peaks reveal $\mathrm{Ca}, \mathrm{P}, \mathrm{Mg}$ and $\mathrm{O}$ elements.
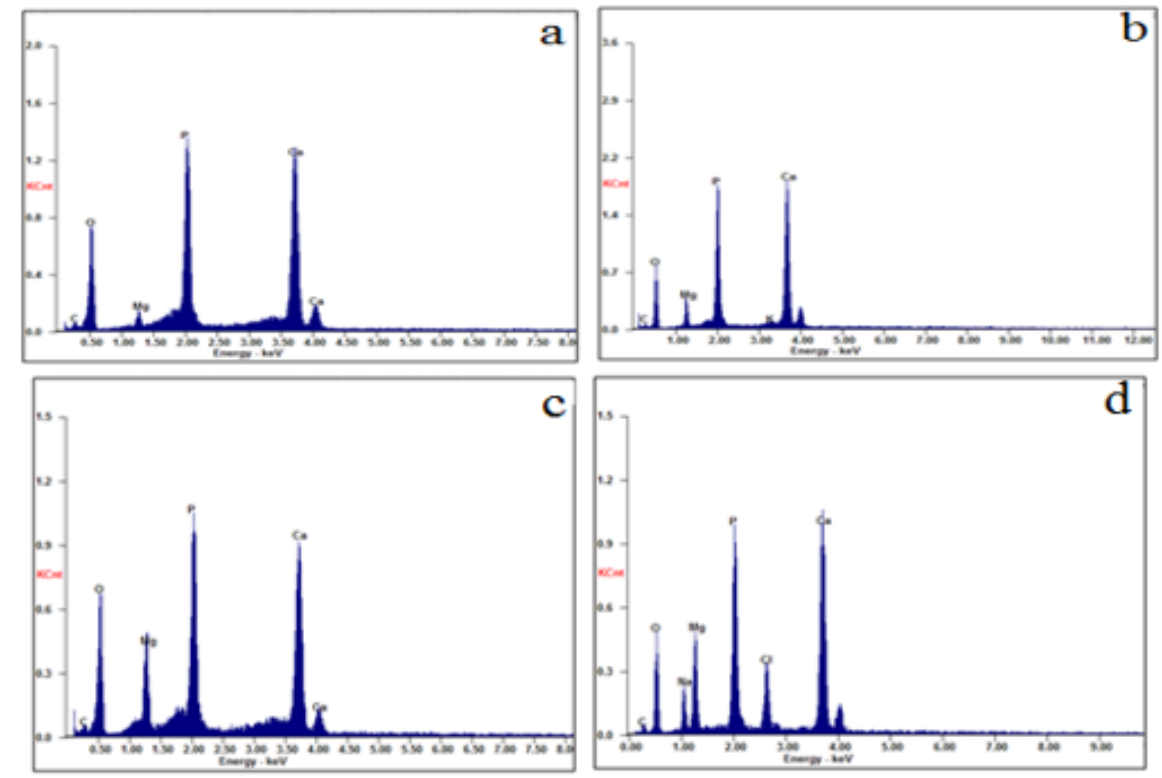

Figure 12. EDAX of Mg- 6\%Znas deposited from a) Bath I b) Bath II c) Bath III

X-ray diffraction patterns of the corrosion product from coated specimens with bath I, bath II, bath III and bath IV for two weeks and four weeks are shown in Figures 13( a, b), Figures 14( a, b), Figures 15(a, b) and Figures 16(a, b). 


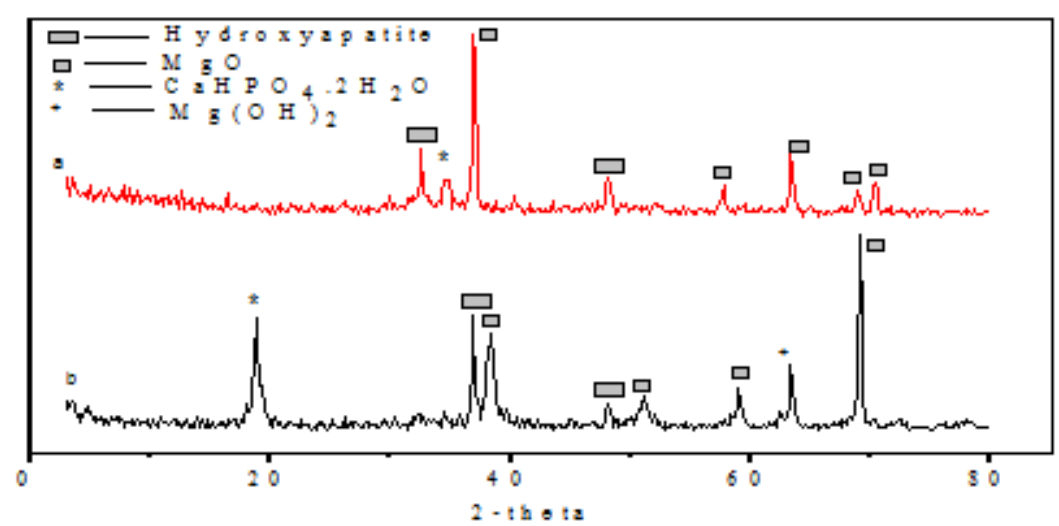

Figure 13. X-ray diffraction patterns of $\mathrm{Mg}-6 \% \mathrm{Zn}$ as deposited from Bath I after immersion in SBF for a) two weeks and b) four weeks

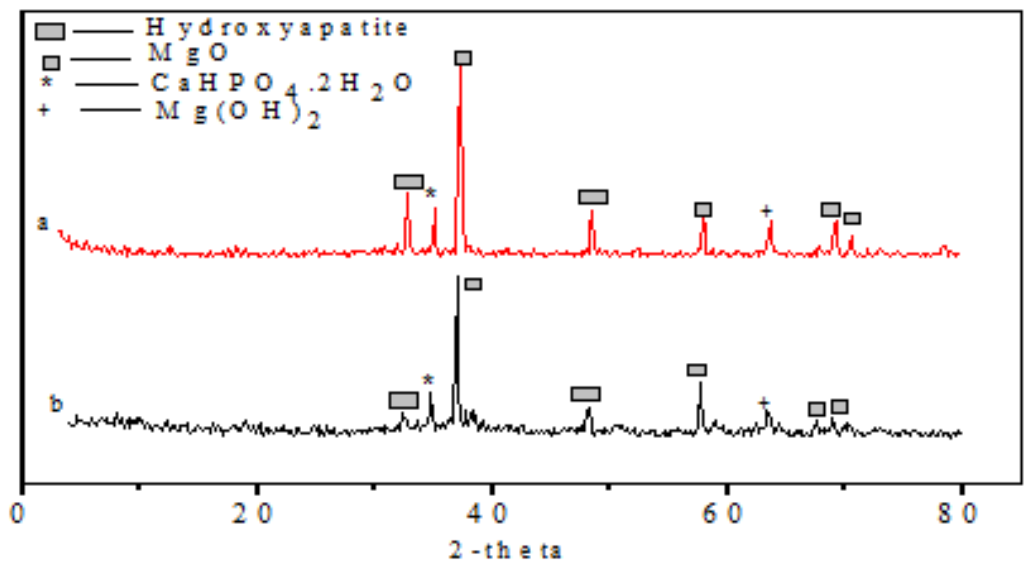

Figure 14. X-ray diffraction patterns of $\mathrm{Mg}-6 \% \mathrm{Zn}$ as deposited from Bath II after immersion in SBF for a) two weeks and b) four weeks

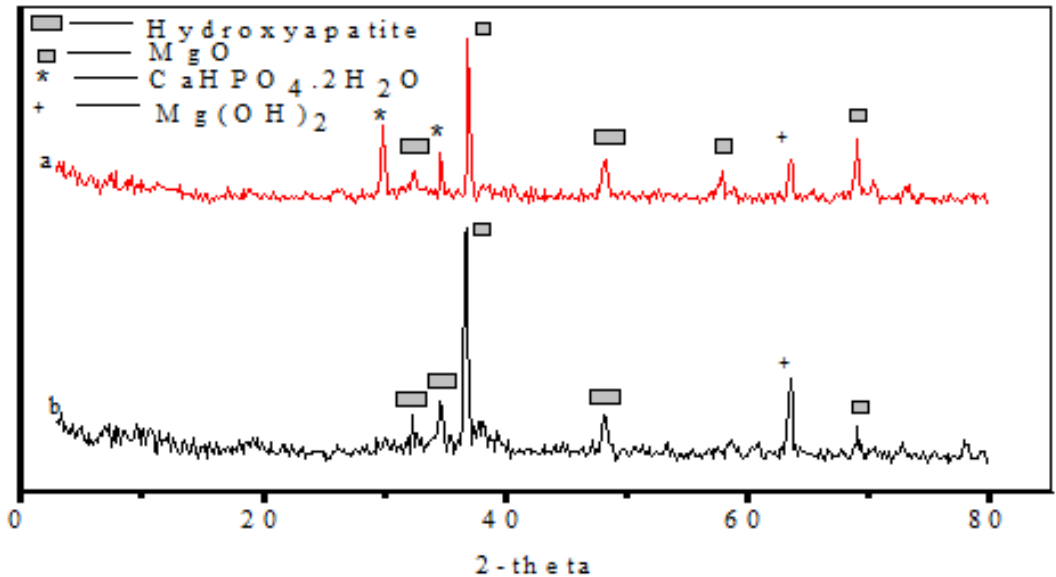

Figure 15. X-ray diffraction pattern of $\mathrm{Mg}-6 \% \mathrm{Zn}$ as deposited from Bath III after immersion in SBF for a) two weeks and b) four weeks 


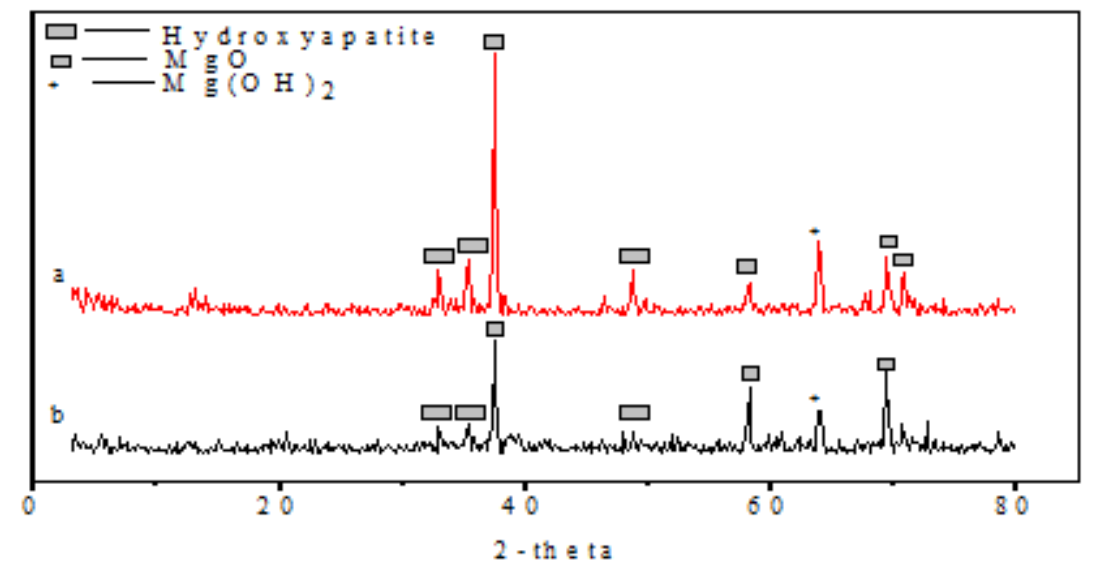

Figure 16. X-ray diffraction patterns of $\mathrm{Mg}$ - $6 \% \mathrm{Zn}$ (Bath IV) after immersion in SBF for a) two weeks and b) four weeks

Figures 17-20 represent the EDAX analysis of the corrosion product of coated specimens by the four bathes after immersion in SBF for two and four weeks.

The EDAX analysis of the corrosion product from bath I in case of immersion for two weeks reveal the presence of $\mathrm{Cl}, \mathrm{Mg}, \mathrm{Ca}, \mathrm{P}$ and $\mathrm{O}$ elements. In agreement with $\mathrm{X}$-ray diffraction since calcium hydrogen phosphate dihydrate $\mathrm{CaHPO}_{4}\left(\mathrm{H}_{2} \mathrm{O}\right)_{2}$, hydroxyapatite $\mathrm{Ca}_{5}\left(\mathrm{PO}_{4}\right)_{3}(\mathrm{OH})$ and magnesium oxide $\mathrm{MgO}$ phases are present. X-ray diffraction of the corrosion products after four weeks give calcium hydrogen phosphate dihydrate $\mathrm{CaHPO}_{4}\left(\mathrm{H}_{2} \mathrm{O}\right)_{2}$, hydroxyapatite $\mathrm{Ca}_{5}\left(\mathrm{PO}_{4}\right)_{3}(\mathrm{OH})$, magnesium hydroxide $\mathrm{Mg}(\mathrm{OH})_{2}$ and magnesium oxide $\mathrm{MgO}$ phases. With increasing of immersion time to four weeks, the peaks of $\mathrm{Ca}$ and $\mathrm{P}$ continued to increase and $\mathrm{Mg}$ peaks continued to decrease as shown in Figure 20(b). This continuous growing of hydroxyapatite with immersion of four weeks, obviously confirms the bioactivity of the coating.

EDAX analysis for the corrosion products obtained from bath II coating after two weeks immersion Figure 18(a) and for four weeks Figure 18(b) reveal the presence of $\mathrm{Cl}, \mathrm{Mg}, \mathrm{Ca}, \mathrm{P}$ and $\mathrm{O}$ elements in agreement with $\mathrm{X}$-ray diffraction that the phases are calcium hydrogen phosphate dihydrate $\mathrm{CaHPO}_{4}\left(\mathrm{H}_{2} \mathrm{O}\right)_{2}$, hydroxyapatite $\mathrm{Ca}_{5}\left(\mathrm{PO}_{4}\right)_{3}(\mathrm{OH})$, magnesium hydroxide $\mathrm{Mg}(\mathrm{OH})_{2}$ and magnesium oxide $\mathrm{MgO}$.
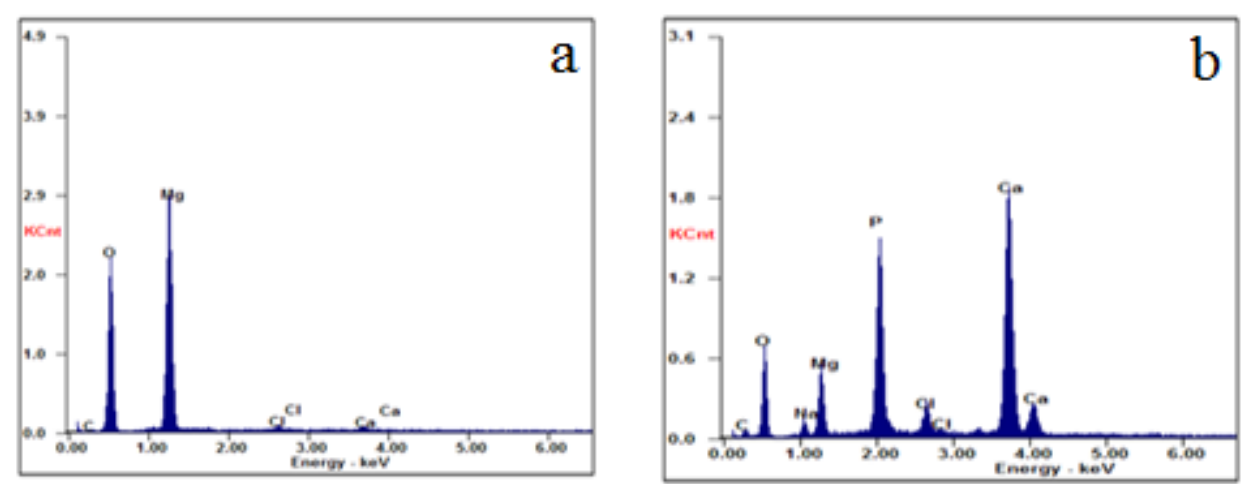

Figure 17. EDAX of Mg- $6 \% \mathrm{Zn}$ as deposited from Bath Ifor a) two weeks b) four weeks 

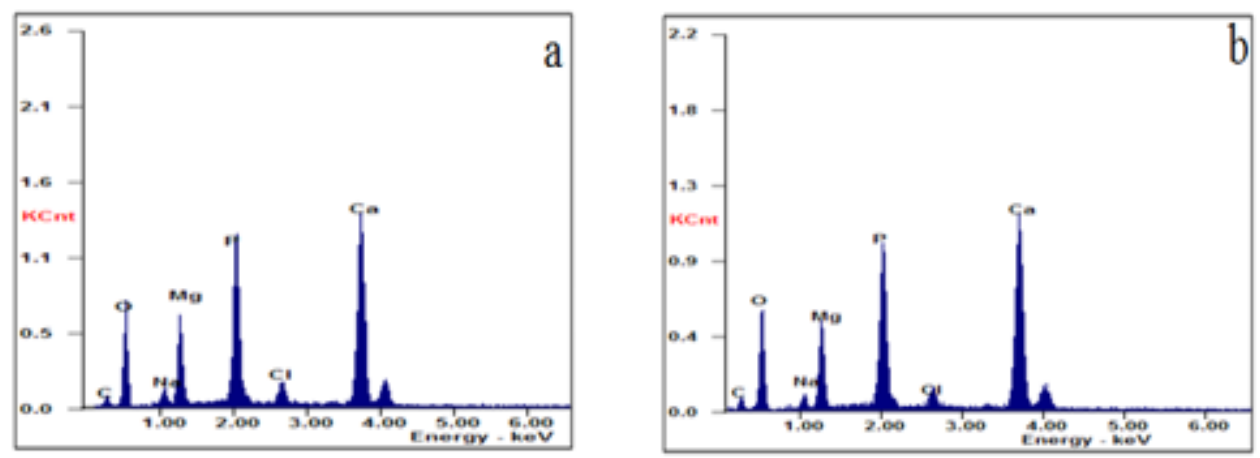

Figure 18. EDAX of Mg- $6 \% \mathrm{Zn}$ as deposited from Bath II for a) two weeks b) four weeks

It is observed from the EDAX spectrum of the coated specimens with bath III, after immersion of two weeks and four weeks in SBF that well resolved peaks corresponding to different elements $\mathrm{Ca}, \mathrm{P}$, $\mathrm{O}, \mathrm{Mg}$ and $\mathrm{Cl}$ are present in Figures 19(a, b) and confirm the synthesis of hydroxyapatite $\mathrm{Ca}_{5}\left(\mathrm{PO}_{4}\right)_{3}(\mathrm{OH})$, calcium hydrogen phosphate dihydrate $\mathrm{CaHPO}_{4}\left(\mathrm{H}_{2} \mathrm{O}\right)_{2}$, magnesium oxide $\mathrm{MgO}$ and magnesium hydroxide $\mathrm{Mg}(\mathrm{OH})_{2}$ phases. In agreement with $\mathrm{X}$-ray diffraction for two weeks immersion in the SBF. In case of dipping four weeks hydroxyapatite $\mathrm{Ca} 5(\mathrm{PO} 4) 3(\mathrm{OH})$, magnesium oxide $\mathrm{MgOand}$ magnesium hydroxide $\mathrm{Mg}(\mathrm{OH})_{2}$ phases are appeared. Average grain size of the coat in bath III is 53.5 - $35.8 \mathrm{~nm}$. A single unwanted peak of $\mathrm{Na}$ is observed which might be due to the foreign impurity.
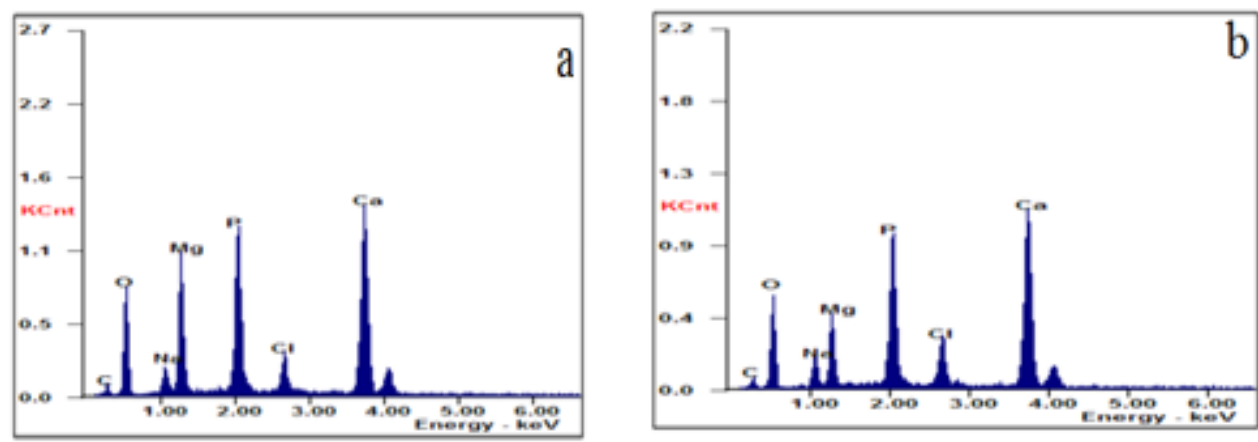

Figure 19. EDAX of $\mathrm{Mg}-6 \% \mathrm{Zn}$ as deposited from

Bath III for a) two weeks b) four weeks

Figures $20(a, b)$ show the EDAX results of the coating obtained from bath IV after immersion in SBF solution for two and four weeks. Strong peaks of calcium $(\mathrm{Ca})$, phosphorous $(\mathrm{P})$, magnesium $(\mathrm{Mg})$ and oxygen $(\mathrm{O})$ and several small peaks are observed. The phases obtained from the XRD results of the coating after immersion in $\mathrm{SBF}$ for two weeks and $\mathrm{MgO}$ four weeks, hydroxyapatite $\mathrm{Ca}_{5}\left(\mathrm{PO}_{4}\right)_{3}(\mathrm{OH})$, magnesium oxide $\mathrm{MgO}$ and magnesium hydroxide $\mathrm{Mg}(\mathrm{OH})_{2}$ phases appear. average grain size of the coat in bath IV is $46.7-34.1 \mathrm{~nm}$. 

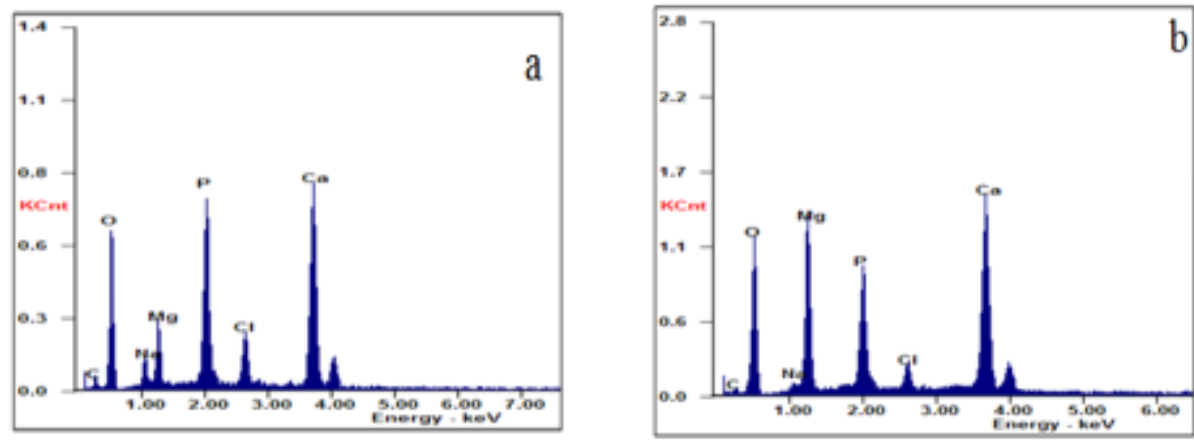

Figure 20. EDAX of Mg- $6 \% \mathrm{Zn}$ as deposited from

Bath IV for a) two weeks b) four weeks

Potentiodynamic polarization studies:

Figure 21 shows Potentiodynamic polarization curves of the $\mathrm{Mg}-6 \% \mathrm{Zn}$ alloy substrate coated with bath I, II, III and IV in SBF. The corrosion potential ( $\left.\mathrm{E}_{\text {corr }}\right)$, corrosion current density (Icorr) and the anodic and cathodic Tafel constants $(\beta \mathrm{a}, \beta \mathrm{c})$ are extracted directly from the Potentiodynamic polarization curves using Tafel extrapolation and linear polarization methods [13].

The polarization resistance (RP) is calculated by Stern- Geary equation (Eq. (1) [24, 25])

$$
\mathrm{RP}=(\beta \mathrm{a} X \beta \mathrm{c}) /(2.3 \mathrm{Xicorr}(\beta \mathrm{a}+\beta \mathrm{c}))
$$

All the electrochemical parameters calculated from Tafel plots are listed in Table 2. It is shown that the treated samples with a lower $\mathrm{I}_{\text {corr }}$, positive $\mathrm{E}_{\text {corr }}$ and higher RP have a good corrosion resistance. The corrosion resistance of samples is improved after the surface coating by the four bathes. By comparing the data $\mathrm{E}_{\text {corr }}$ and $\mathrm{I}_{\text {corr }}$ of bath IV coated sample are $-1.441 \mathrm{v}$ and $1.200 \times 10^{-4} \mathrm{~A} / \mathrm{cm}^{2}$ respectively. $E_{\text {corr }}(-1.710)$ of coated sample with bath $I$ is slightly less than that of coated by bath IV, while the Icorr $\left(6.16 \times 10-4 \mathrm{~A} / \mathrm{cm}^{2}\right)$ is reduced. In addition, RP (543.65) of bath IV coat is reduced to 142.73 for bath I coat. It is indicated that bath IV treated sample has higher corrosion resistance than bath III, bath II and bath I. The refinement of the microstructure is good for improving the corrosion resistance of the coated $\mathrm{Mg}-6 \% \mathrm{Zn}$. The corrosion protection of coated samples in SBF follows the sequence Bath IV >Bath III > Bath II > Bath I.

Table 3. The corrosion kinetic parameters $E_{\text {corr }}, I_{c o r r}, C_{R}$ and $R_{P}$ determined from the polarization curves in the Tafel region for the four bathes in simulated body fluid

\begin{tabular}{|c|c|c|c|c|c|c|}
\hline Bath & $\mathrm{E}_{\text {corr }}(\mathrm{V})$ & $\mathrm{I}_{\text {corr }}\left(\mathrm{A} / \mathrm{cm}^{2}\right)$ & $\mathrm{C}_{\mathrm{R}}$ & $\beta_{\mathrm{a}}(\mathrm{V})$ & $\beta_{\mathrm{c}}(\mathrm{V})$ & $\mathrm{R}_{\mathrm{P}}$ \\
\hline Bath I & -1.710 & $6.16 \times 10^{-4}$ & $4.26 \times 10^{-4}$ & 0.261 & 0.950 & 142.73 \\
\hline Bath II & -1.620 & $5.01 \times 10^{-4}$ & $3.47 \times 10^{-4}$ & 0.250 & 0.91 & 170.19 \\
\hline Bath III & -1.570 & $4.46 \times 10^{-4}$ & $3.09 \times 10^{-4}$ & 0.228 & 0.88 & 175.96 \\
\hline Bath IV & -1.441 & $1.200 \times 10^{-4}$ & $0.83 \times 10^{-4}$ & 0.183 & 0.850 & 543.65 \\
\hline
\end{tabular}




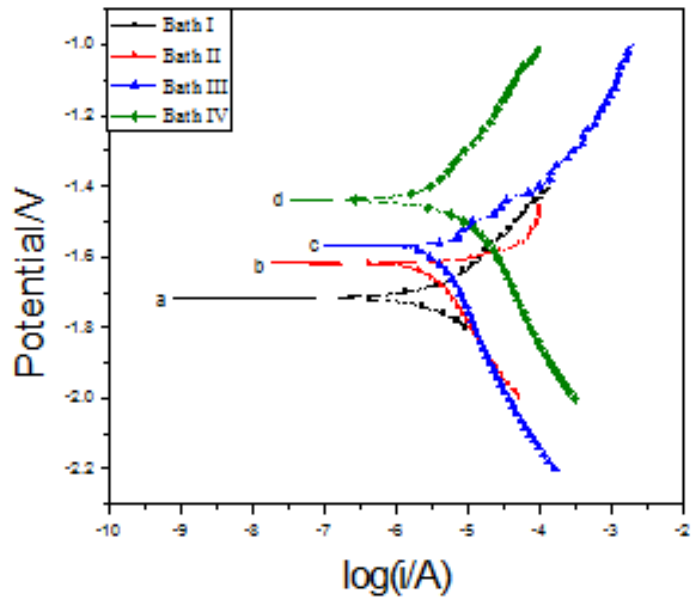

Figure 21. Potentiodynamic polarization curves of the $\mathrm{Mg}-6 \% \mathrm{Zn}$ alloy substrate coated with a) Bath I b) Bath II c) Bath III d) Bath IV in SBF

Figure 22 shows Potentiodynamic polarization curves of a coat substrate by bath I before and after immersion in SBF for two and four weeks. The corrosion potential of the substrate coat $-1.710 \mathrm{v}$

For four weeks show the best corrosion resistance than which immersed for two weeks and finally the coated substrate. Table (4) shows the corresponding Ecorr and Icorr for the pervious results.

The same results are observed for the other bathes as shown in Figures 23- 25 and Tables 5-7.

Table 4. The corrosion kinetic parameters $E_{c o r r}, I_{c o r r}, C_{R}$ and $R_{P}$ determined from the polarization curves in the Tafel region for bath I in simulated body fluid

\begin{tabular}{|c|c|c|c|c|c|c|}
\hline Bath & $\mathrm{E}_{\text {corr }}(\mathrm{V})$ & $\mathrm{I}_{\text {corr }}\left(\mathrm{A} / \mathrm{cm}^{2}\right)$ & $\mathrm{C}_{\mathrm{R}}$ & $\beta_{\mathrm{a}}(\mathrm{V})$ & $\beta_{\mathrm{c}}(\mathrm{V})$ & $\mathrm{R}_{\mathrm{P}}$ \\
\hline Bath I & -1.710 & $6.16 \times 10^{-4}$ & $4.26 \times 10^{-4}$ & 0.26 & 0.95 & 142.73 \\
\hline Bath I(2weeks) & -1.381 & $4.36 \times 10^{-4}$ & $3.02 \times 10^{-4}$ & 0.21 & 0.77 & 164.53 \\
\hline Bath I(4 weeks) & -0.457 & $0.57 \times 10^{-4}$ & $0.39 \times 10^{-4}$ & 0.13 & 0.61 & 810.29 \\
\hline
\end{tabular}

Table 5. The corrosion kinetic parameters $E_{c o r r}, I_{c o r r}, C_{R}$ and $R_{P}$ determined from the polarization curves in the Tafel region forbath II in simulated body fluid

\begin{tabular}{|c|c|c|c|c|c|c|}
\hline Bath & $\mathrm{E}_{\text {corr }}(\mathrm{V})$ & $\mathrm{I}_{\text {corr }}\left(\mathrm{A} / \mathrm{cm}^{2}\right)$ & $\mathrm{C}_{\mathrm{R}}$ & $\beta_{\mathrm{a}}(\mathrm{V})$ & $\beta_{\mathrm{c}}(\mathrm{V})$ & $\mathrm{R}_{\mathrm{P}}$ \\
\hline Bath II & -1.620 & $5.01 \times 10^{-4}$ & $3.47 \times 10^{-4}$ & 0.250 & 0.91 & 170.19 \\
\hline Bath II (2weeks) & -1.361 & $3.63 \times 10^{-4}$ & $2.51 \times 10^{-4}$ & 0.194 & 0.74 & 183.38 \\
\hline Bath II(4weeks) & -0.450 & $0.52 \times 10^{-4}$ & $0.36 \times 10^{-4}$ & 0.123 & 0.58 & 844.44 \\
\hline
\end{tabular}

Table 6. The corrosion kinetic parameters $E_{\text {corr }}, I_{c o r r}, C_{R}$ and $R_{P}$ determined from the polarization curves in the Tafel region for bath III in simulated body fluid

\begin{tabular}{|c|c|c|c|c|c|c|}
\hline Bath & $\mathrm{E}_{\text {corr }}(\mathrm{V})$ & $\mathrm{I}_{\text {corr }}\left(\mathrm{A} / \mathrm{cm}^{2}\right)$ & $\mathrm{C}_{\mathrm{R}}$ & $\beta_{\mathrm{a}}(\mathrm{V})$ & $\beta_{\mathrm{c}}(\mathrm{V})$ & $\mathrm{R}_{\mathrm{P}}$ \\
\hline Bath III & -1.570 & $4.46 \times 10^{-4}$ & $3.09 \times 10^{-4}$ & 0.228 & 0.88 & 175.96 \\
\hline Bath III(2weeks) & -1.269 & $2.39 \times 10^{-4}$ & $1.65 \times 10^{-4}$ & 0.186 & 0.67 & 263.52 \\
\hline Bath III(4 weeks) & -0.287 & $0.48 \times 10^{-4}$ & $0.33 \times 10^{-4}$ & 0.120 & 0.53 & 886.28 \\
\hline
\end{tabular}

Table 7. The corrosion kinetic parameters $E_{\text {corr }}, I_{c o r r}, C_{R}$ and $R_{P}$ determined from the polarization curves in the Tafel region for bath IV in simulated body fluid

\begin{tabular}{|c|c|c|c|c|c|c|}
\hline Bath & $\mathrm{E}_{\text {corr }}(\mathrm{V})$ & $\mathrm{I}_{\text {corr }}\left(\mathrm{A} / \mathrm{cm}^{2}\right)$ & $\mathrm{C}_{\mathrm{R}}$ & $\beta_{\mathrm{a}}(\mathrm{V})$ & $\beta_{\mathrm{c}}(\mathrm{V})$ & $\mathrm{R}_{\mathrm{P}}$ \\
\hline Bath IV & -1.441 & $1.200 \times 10^{-4}$ & $0.830 \times 10^{-4}$ & 0.183 & 0.850 & 543.65 \\
\hline Bath IV (2weeks) & -1260 & $0.350 \times 10^{-4}$ & $0.240 \times 10^{-4}$ & 0.177 & 0.620 & 1698.91 \\
\hline Bath IV (4weeks) & -0.107 & $0.154 \times 10^{-4}$ & $0.106 \times 10^{-4}$ & 0.110 & 0.510 & 2550.04 \\
\hline
\end{tabular}



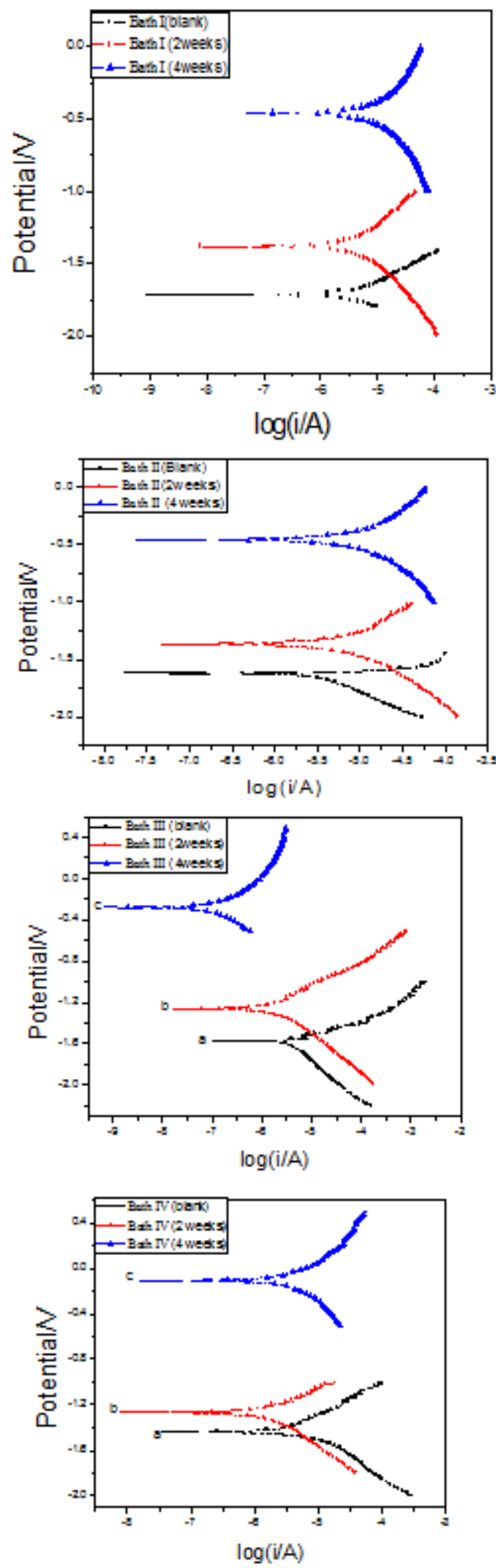

Figure 22. Potentiodynamic polarization curves of the $\mathrm{Mg}-6 \%$ Zn alloy substrate coated with bath I in SBF a) blank b) 2 weeks c) 4 weeks

Figure 23. Potentiodynamic polarization curves of the $\mathrm{Mg}-6 \%$ $\mathrm{Zn}$ alloy substrate coated with bath II in SBF a) blank b) 2 weeks c) 4 weeks

Figure 24. Potentiodynamic polarization curves of the Mg- 6\% Zn alloy substrate coated with bath III in SBF a) blank b) 2 weeks c) 4 weeks

Figure 25. Potentiodynamic polarization curves of the $\mathrm{Mg}-6 \% \mathrm{Zn}$ alloy substrate coated with bath IV in SBF a) blank b) 2 weeks c) 4 weeks

\section{Conclusions}

We study the electrodeposition of the four bathes on $\mathrm{Mg}-6 \% \mathrm{Zn}$ alloy. The surface morphology of the coat have flake- like structure.

FTIR analysis show the present of hydroxyl, nitrate, phosphate, hydrogen phosphate groups. 
X-ray diffraction pattern indicated that the structure of the coat incase of I, II, III, and IV is monoclinic calcium phosphate dihydrate, hexagonal magnesium, calcium oxide, magnesium oxide and magnesium hydroxide.

The elements percentage of the constituents in the coat of the implants is shown from EDAX analysis. The elements are $\mathrm{Mg}, \mathrm{P}, \mathrm{Zn}, \mathrm{Ca}$ and $\mathrm{O}$.

Then we test the protection of the coated alloys in the SBF immediately and after different periods of immersion two and four weeks.

The Potentiodynamic polarization of the implants uncoated and coated by the different four bathes are studied in simulated body fluid. The results show that IV > III $>$ II > I.

Potentiodynamic polarization measurements show that the coated alloys have more corrosion resistance than the uncoated ones.

Also as the immersion time of the coated alloys increase in SBF, the corrosion protection increase following the sequence IV $>$ III $>$ II $>$ I.

\section{References}

1.YONGJUN CHEN, ZHIGANG XU, CHRISTOPHER SMITH, JAG SANKAR, Recent advances on the development of magnesium alloys for biodegradable implants, ActaBiomaterialia, 10 (11), 2014, 4561-4573.

2.CAI, S. H. LEI, T. LI, N. F. FENG, F. F. Effects of Zn on microstructure, mechanical properties and corrosion behavior of $\mathrm{Mg}-\mathrm{Zn}$ alloys. Materials Science \& Engineering C-Materials for Biological Applications. 32(8), 2012, 2570-2577.

3.FARE S, GE QA, VEDANI M, VIMERCATI G, GASTALDI D, MIGLIAVACCA F, et al. Evaluation of material properties and design requirements for biodegradable magnesium stents. Materia-Brazil 103, 2010, 12-15

4.DING, YUN-FEI\& WEN, CUIE \& HODGSON, PETER \& LI, YUNCANG, Effects of alloying elements on the corrosion behavior and biocompatibility of biodegradable magnesium alloys: A review. J. Mater. Chem. B. 2. 10.1039/C3TB21746A, 2014.

5.SONG M-SHI, ZENG R-CHANG, DING Y-FEI, LI RW, EASTON M, COLE I, BIRBILIS N, CHEN X-BO, Recent advances in biodegradation controls over $\mathrm{Mg}$ alloys for bone fracture management: A review, Journal of Materials Science and amp; Technology (2018).

6.WITTE F, FISCHER J, NELLESEN J, CROSTACK HA, KAESE V, PISCH A, et al. In vitro and in vivo corrosion measurements of magnesium alloys. Biomaterials 2006;27:1013-8.

7.S. ZHANG, X. ZHANG, C. ZHAO, J. LI, Y. SONG, C. XIE, H. TAO, Y. ZHANG, Y. HE, Y. JIANG, Y. BIAN, Research on an Mg-Zn alloy as a degradable biomaterial, Acta Biomater. 6(2) (2010) 626-640.

8.B. ZBERG, P.J. UGGOWITZER, J.F. LÖFFLER, MgZnCa glasses without clinically observable hydrogen evolution for biodegradable implants, Nat. Mater. 8 (2009) 887.

9.X.-B. CHEN, N.T. KIRKLAND, H. KREBS, M.A. THIRIAT, S. VIRTANEN, D. NISBET, N. BIRBILIS, In vitro corrosion survey of $\mathrm{Mg}-\mathrm{xCa}$ and $\mathrm{Mg}-3 \mathrm{Zn}-\mathrm{yCa}$ alloys with and without calcium phosphate conversion coatings, Corros. Eng. Sci. Tech. 47(5) (2012) 365-373.

10.P.K. BOWEN, J. DRELICH, J. GOLDMAN, Zinc exhibits ideal physiological corrosion behavior for bioabsorbable stents, Adv. Mater. 25(18) (2013) 2577-2582.

11.JUN, J., HWANG, I. Damping Capacities of Mg-4 Pct Zn-(0-0.5) Pct Ca Biomedical Alloys. Metall and Mat Trans A 47, 4784-4787 (2016).

12.Y. ZHANG, J. XU, Y.C. RUAN, M.K. YU, M. O'LAUGHLIN, H. WISE, D. CHEN, L. TIAN, D. SHI, J. WANG, S. CHEN, J.Q. FENG, D.H.K. CHOW, X. XIE, L. ZHENG, L. HUANG, S. HUANG, K. LEUNG, N. LU, L. ZHAO, H. LI, D. ZHAO, X. GUO, K. CHAN, F. WITTE, H.C. CHAN, Y. ZHENG, L. QIN, Implant-derived magnesium induces local neuronal production of CGRP to improve bone-fracture healing in rats, Nat. Med. 22 (2016) 1160. 
13.DONGJIE HU, JIN ZHANG, RUIYUE HANG, CHUNLIN LI, YONGHUA SUN, XIAOHONG YAO, RUIQIANG HANG, Effects of solid diffusion zinc treatment on corrosion behavior, antibacterial ability, and cytocompatibility of AZ31B magnesium alloy, Materials Letters, 251, 2019, 30-33.

14.T. BHATTACHARJEE, T. NAKATA, T.T. SASAKI, S. KAMADO, K. HONO, Effect of microalloyed $\mathrm{Zr}$ on the extruded microstructure of Mg-6.2Zn-based alloys, Scripta Mater. 90- 91 (2014) 37-40.

15.O. R. M. KHALIFA, E. A. AL HAMED, A. KASSAB, A. H. TILP, M. Esmail, Characterization of different bathes producing hydroxyapatite coating on $\mathrm{Mg}-1 \% \mathrm{Zn}$ alloy for implant application, journal ofscientific research in science, 36 (1), 2019, 140-160.

16.XUENANGU, YUFENG ZHENG, YAN CHENG, SHENGPINGZHONG, TINGFEI XI, In vitro corrosion and biocompatibility of binary magnesium alloys, Biomaterials, 30(4), 2009, 484-498.

17.XIAN-BIN LIU, DA-YONG SHAN, YING-WEI SONG, EN-HOU HAN, Effects of heat treatment on corrosion behaviors of Mg-3Zn magnesium alloy, Transactions of Nonferrous Metals Society of China, 20(7), 2010, 1345-1350.

18.SHAOXIANG ZHANG, XIAONONG ZHANG, CHANGLI ZHAO, JIANAN LI, YANG SONG, CHAOYINGXIE, HAIRONG TAO, YAN ZHANG, YAOHUA HE, YAO JIANG, YUJUNBIAN, Research on an Mg-Zn alloy as a degradable biomaterial, ActaBiomaterialia, 6(2), 2010, 626-640.

19.Y.F. ZHENG, X.N. GU, Y.L. XI, D.L. CHAI, In vitro degradation and cytotoxicity of $\mathrm{Mg} / \mathrm{Ca}$ composites produced by powder metallurgy, ActaBiomater, 6 (2010), 1783-1791.

20.D. BELluCCI, A. SOlA, M. GAZZARRI, F. CHIELLINI, V. CANNILlO, A new hydroxyapatite-based biocomposite for bone replacement, Mater. Sci. Eng.: C 33 (3) (2013) 10911101.

21.H. WANG, W. ZHI, X. LU, X. LI, K. DUAN, R. DUAN, Y. MU, J. WENG, Comparative studies on ectopic bone formation in porous hydroxyapatite scaffolds with complementary pore structures, Acta Biomater. 9 (9) (2013) 8413-8421

22.B. NASIRI-TABRIZI, A. FAHAMI, R. EBRAHIMI-KAHRIZSANGI, A comparative study of hydroxyapatite nanostructures produced under different milling conditions and thermal treatment of bovine bone, J. Ind. Eng. Chem. 20 (1) (2014) 246-258.

23.M. SADAT-SHOJAI, M.-T. KHORASANI, E. DINPANAH-KHOSHDARGI, A. JAMSHIDI, Synthesis methods for nanosized hydroxyapatite with diverse structures, Acta Biomater. 9 (8) (2013) 7591-7621.

24.M.H FATHI, ,M SALEHI, A SAATCHI, V MORTAZAVI, S.B MOOSAVI, In vitro corrosion behavior of bioceramimetallic, and bioceramic-metallic coated stainless steel dental implants, Dent. Mater. J., 19, 2003, 188-198.

25.HONGPING DUAN,CHUANWEI YAN, FUHUI WANG, Effect of electrolyte additives on performance of plasma electrolytic oxidation films formed on magnesium alloy AZ91D, Electrochimica Acta, 52, 2007, 3785-3793

$\overline{\text { Manuscript received: } 25.02 .2020}$ 